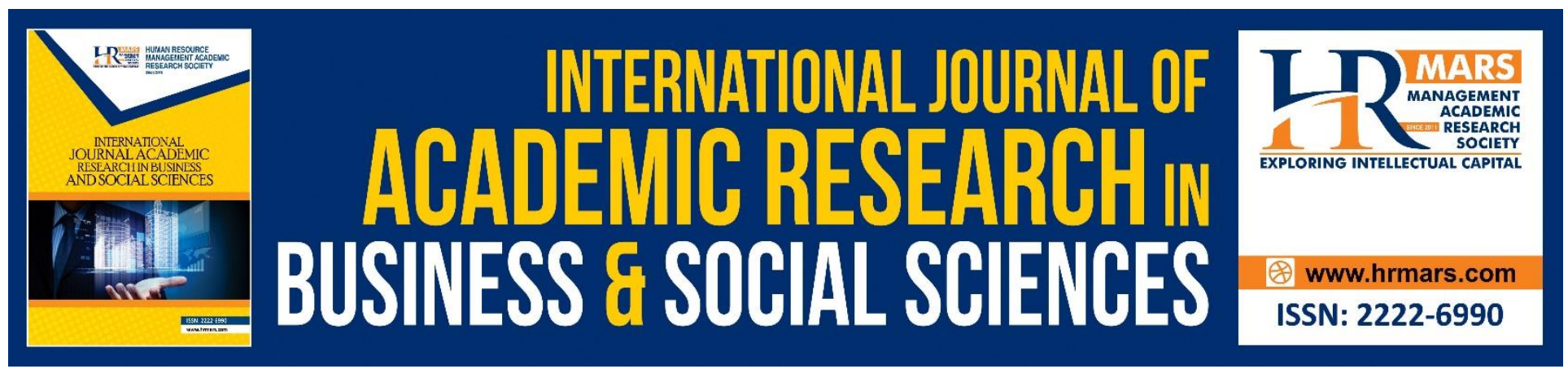

\title{
Engaging Undergraduates in Wikis and Regulation Activities to Improve Collaborative Writing Process
}

\author{
Or-Kan, Soh
}

To Link this Article: http://dx.doi.org/10.6007/IJARBSS/v8-i12/5087

DOI: $10.6007 /$ IJARBSS/v8-i12/5087

Received: 19 Oct 2018, Revised: 14 Dec 2018, Accepted: 19 Dec 2018

Published Online: 26 Dec 2018

In-Text Citation: (Or-Kan, 2018)

To Cite this Article: Or-Kan, S. (2018). Engaging Undergraduates in Wikis and Regulation Activities to Improve Collaborative Writing Process. International Journal of Academic Research in Business and Social Sciences, 8(12), 932-947.

Copyright: (C) 2018 The Author(s)

Published by Human Resource Management Academic Research Society (www.hrmars.com)

This article is published under the Creative Commons Attribution (CC BY 4.0) license. Anyone may reproduce, distribute, translate and create derivative works of this article (for both commercial and non-commercial purposes), subject to full attribution to the original publication and authors. The full terms of this license may be seen

at: http://creativecommons.org/licences/by/4.0/legalcode

\section{Vol. 8, No. 12, 2018, Pg. 932 - 947}

Full Terms \& Conditions of access and use can be found at http://hrmars.com/index.php/pages/detail/publication-ethics 


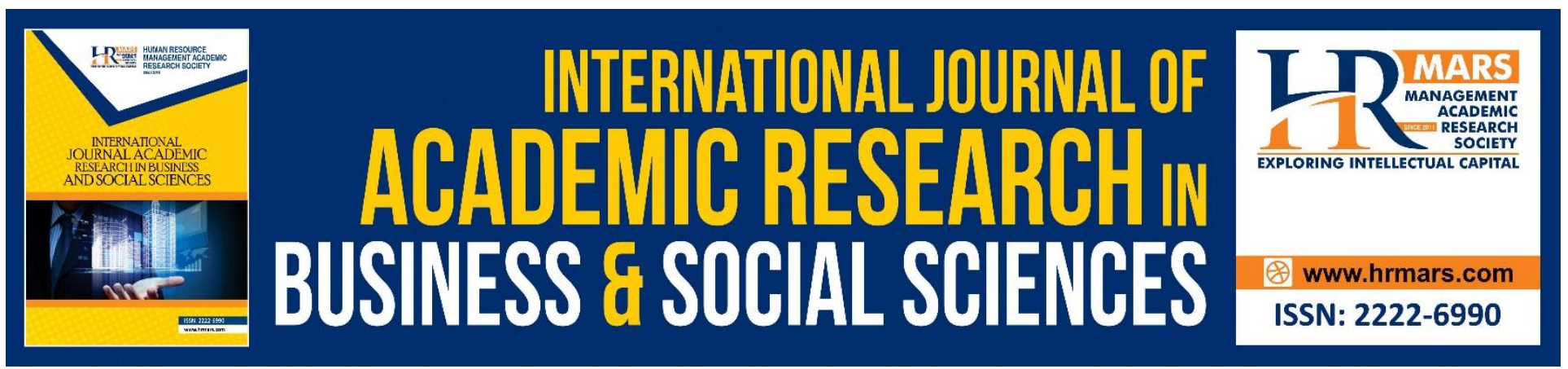

\title{
Engaging Undergraduates in Wikis and Regulation Activities to Improve Collaborative Writing Process
}

\author{
Or-Kan, Soh \\ The School of Language Studies \& Linguistics, Universiti Kebangsaan Malaysia, Malaysia \\ 43600 UKM Bangi, Selangor, Malaysia. \\ Email: sok@ukm.edu.my
}

\begin{abstract}
Wikis have been used as a platform to support collaborative writing but its effectiveness and the level of students' participation remain unknown. In this study, regulation theories were used to design interventions. The purpose of this study was to examine the functions of wikis in improving students' collaborative writing process. From the results of this study, we could conclude that the level of confidence among students has been significantly motivated and the anxiety about writing has been reduced because of the activities in interventions. An analysis on log files have shown that $83 \%$ of the students proactively participated in collaborative writing process. Wikis were used as a platform to encourage students to give their voice in writing. Recommendations are suggested for educational developers and instructors to effectively design collaborative writing on wikis.
\end{abstract}

Keywords: Undergraduates, Wikis, Collaborative Writing, Regulation Activities, Process

\section{Introduction}

Over the last 30 years, the reformation in technology has changed the conventional ways of teaching writing but it has not achieved the unified, durable and validated research outcomes (Chappelle, 1997; Felix, 2005; Stockwell, 2007a). In addition, some researchers (Liu, Lin, \& Zhang, 2017; Hubbard, 2005; Jeong, 2017) have asserted that the lack of relevant data about participants and consistent investigations that enhance the effectiveness of technology and writing process are the common problems. Therefore, the present study demonstrates the ways to enhance collaborative writing on wikis among undergraduates in a university. The findings on intervention practices of this study will be useful not only for instructors but also educational developers. The former can integrate wikis for collaborative writing among undergraduates and the latter can plan the course using wikis as a platform for writing processes and guide the instructors to use wikis in a more effective way.

Wikis are web applications that create a platform for students to perform collaborative writing process as students can contribute their information on wikis (Su \& Beaumont 2010; Wheeler 
\& Wheeler 2009; Witney \& Smallbone 2011). Megele (2015) has acknowledged the benefits of using this virtual space to observe the process of writing, revise and edit the write-ups. He further claimed that individuals and group members can monitor and track ideas that contribute to the collaborative writing process.

Due to the effective features of wikis in supporting collaborative writing, they have been deemed as an innovative learning technology among undergraduates (Soh \& Hong-Fa 2014; Su \& Beaumont 2010; Wheeler \& Wheeler 2009). Su and Beaumont (2010) used wikis for undergraduates' assignments that require them to construct literature reviews for research projects. Wheeler and Wheeler (2009) employed wikis as the platforms and collaborative writing tools for pre-service teachers to key in their journal entries about a course. Soh and Hong Fa (2014) discovered that collaborative writing enables the students to exchange ideas among students and it is able to help the weak students to improve their contents in writing.

Despite wikis have the positive effects on collaborative tasks, educational developers and educators have challenged their effectiveness for collaboration used in higher education settings (De Weaver, Hamalainen, Voet, \& Gielen 2015). Cole (2009) has proven in his study that students are unwilling to be the first person who posts the ideas because they are lack of confidence to share their work on the virtual platform. Karasavvdis (2010) further pointed out about students' unwillingness to edit others' write-ups. Hence, the methods to enhance collaborative writing on wikis among undergraduates has become an instructional issue to be considered when implementing wikis. However, previous empirical studies have scarcely shown that wikis are employed to strengthen the collaboration among undergraduates in the writing process. As a result, this study has contributed to the existing knowledge that the level of confidence among students has been significantly motivated and the anxiety about writing has been reduced because of the activities in interventions.

\section{Literature Review}

\section{Regulation activities to assist students in collaborative writing process}

Successful collaborative writing process needs active students' participations to set goals, monitor the tasks and evaluate the writing performance individually and in groups (Cole 2009; De Waever et al. 2015; Witney \& Smallbone 2011). Individual students are responsible for their writing progress. They have to set clear goals at the initial stage, self-initiated discussions with other group members, self-monitoring systems to benchmark their goals and determine the goal achieved by them (Zimmerman \& Bandura 1994; Zimmerman \& Schunk 2011).

A group has regulate the writing process by establishing the goal of the group, monitoring the whole progress and finally evaluating the accomplishments of the group (Jarvela et al. 2015; Volet, Vauras \& Salonen 2009). After setting the goal, the workload has to be assigned to all the group members based on the due dates. Then, the workload is monitored to ensure it is accomplished on time. The completed workload is evaluated by having discussions among the group members. 
INTERNATIONAL JOURNAL OF ACADEMIC RESEARCH IN BUSINESS AND SOCIAL SCIENCES

Vol. 8, No. 12, Dec, 2018, E-ISSN: 2222-6990 @ 2018 HRMARS

Students' with high and low confidence in writing strategies, the ability to write, writing anxiety Low confidence when applying writing strategies shows the ability to write for that students is comparatively low. They demonstrate writing anxiety and all these factors have given negative effects on students' collaborative writing because the low proficiency students hesitate to revise others' write-ups. However, these low confidence and writing anxiety can be resolved by employing regulation activities such as setting clear goals, self-monitoring and evaluation (Jarvela et al. 2015; Pekrun, Goetz, Daniels, Stupnisky \& Perry 2010).

Bruning and his researchers (2013) has confirmed that regulated writers who are proficient in voicing their ideas in writing are confidence in applying their writing strategies. In Zimmerman and Bandura's (1994) study, they found that regulated students who have the confidence in using writing strategies may help them to obtain good results in a writing course. Bruning and his researchers (2013) found out that students with high confidence in a high school were able to predict writing performance by applying writing strategies in their tasks.

Besides, regulated writers are trained to show their ability to write in which it is related to writing strategies and the grades (Charney, Newman \& Palmquist 1995; Hammann 2005). Therefore, students with the ability to write proficiently have the privilege to secure good scores in their writing assignments (Charney et al. 1995; Hammann 2005).

Students with low confidence and less skillful in the writing process might be anxious about writing. They manifest their anxiety in the writing process when they are required to perform prewriting, drafting, revising and editing. They have to set goals, monitor and evaluate the whole process to improve themselves in writing. Pekrun and his researchers (2010) as well as Martinez and her team (2011) certainly claimed that undergraduates with negative feelings about the process of writing may influence their cognitive processing and achievements in writing.

\section{Research Questions}

In this study, the pre-experimental design was employed to collect data from a single-group. The aim of the treatment was to improve students' involvements in regulation activities by individuals and groups. Before and after the implementations of regulation activities, the single-group students were under careful observation. Hence, specified research questions are as follows.

(1) To what extent do regulation activities affect the students' ability to write, writing strategies and writing anxiety?

(2) What is the relationship between the ability to write, writing strategies, writing anxiety and real writing practices on wikis?

(3) What is the levels of satisfaction when students engage in collaborative writing process and wiki regulation activities? 
INTERNATIONAL JOURNAL OF ACADEMIC RESEARCH IN BUSINESS AND SOCIAL SCIENCES

Vol. 8, No. 12, Dec, 2018, E-ISSN: 2222-6990 C 2018 HRMARS

\section{Research Design}

\section{Demographic information}

There were 30 pre-service teachers (11 males and 19 females) who took part in this research. They have enrolled in a counseling course offered in semester 2 . The average of their age for all the participants was 22.66 (SD = 7.56). None of them had prior experience about wikis.

\section{Research Context}

Students met 2 times weekly for a 3-hour writing class. A collaborative writing project deemed as the final project of the course commenced 6 weeks before the completion of the semester. All the tasks had to be completed in Wikispaces.com. It was chosen as the platform for tasks and communication because of its conveniences and it did not require the students to download additional software. It also allowed students to carry out activities such as putting up writing posts, inviting and authorizing them to view the write-ups and editing the content of the group wikis. Students were comfortable to be a part in collaborative writing process because only invited members were able to edit and view the content in the wikis.

Besides, the account for a group wiki had 8 pages. The page 1 consisted of the details about the project, the group members' names and the marking rubrics. They started their writing task on page 2, meanwhile, the other 6 pages were designed for students to engage in regulation activities. The regulation activities were divided into individuals and in groups. They were also inclusive of weekly regulations $1,2,3,4,5$ and 6.

Table 1 showed the information of collaborative writing process and virtual regulation activities for students in 5 weeks. In group regulation activities, the students were allotted 15-20 minutes to discuss and contribute to the collaborative writing process. 
INTERNATIONAL JOURNAL OF ACADEMIC RESEARCH IN BUSINESS AND SOCIAL SCIENCES Vol. 8, No. 12, Dec, 2018, E-ISSN: 2222-6990 @ 2018 HRMARS

Table 1. Information for collaborative writing process and regulation activities

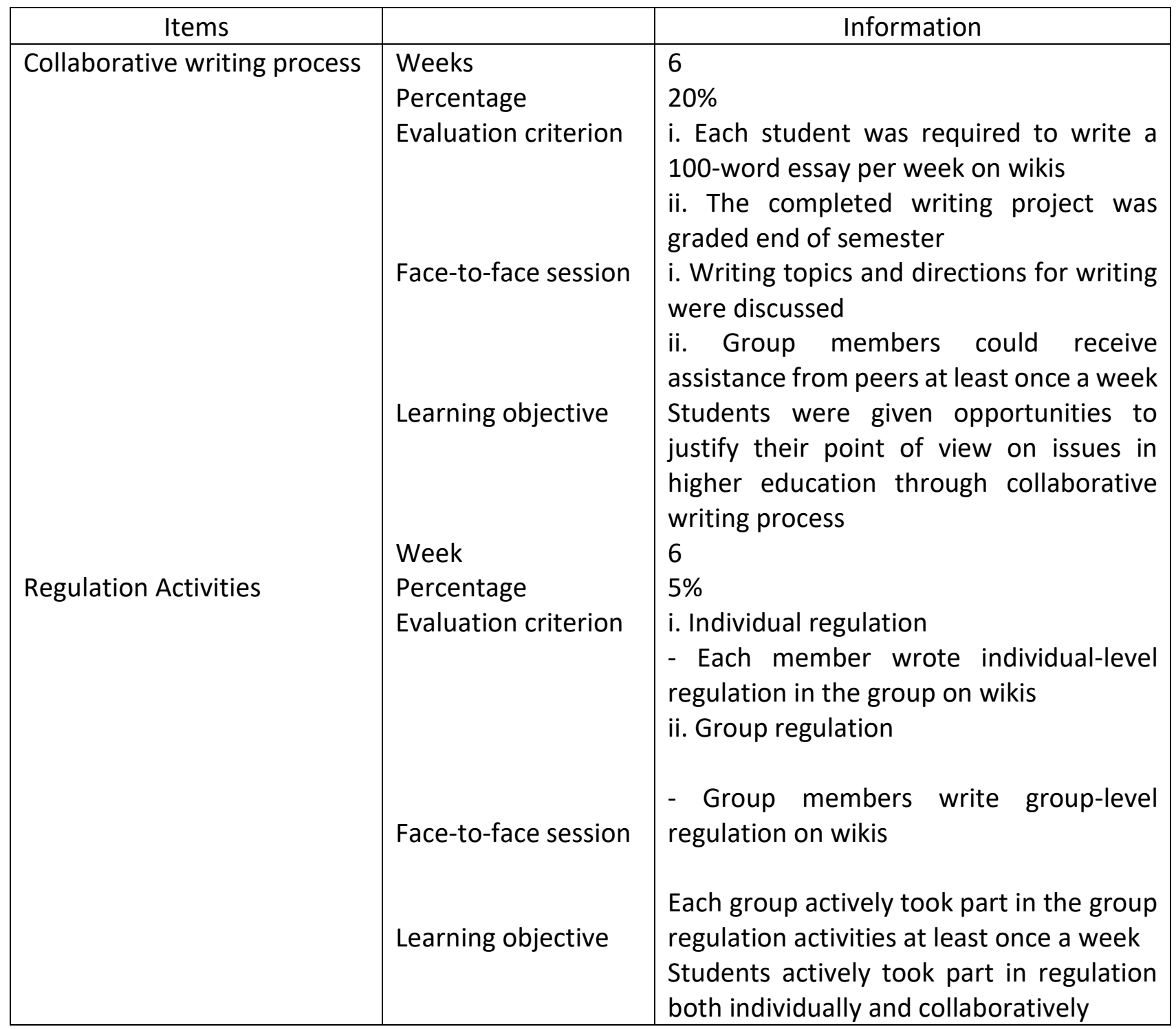

Students were able to choose their groups respectively. Then students in each group collaborated to come up with a academic article on the issue chosen. The students identified issues in higher education relevant to their lives as a student in the university. Finally, the assigned instructor requested the groups to submit the issue and its scopes of their research. An instance of the research topic was "The roles of parents in motivating their children to excel academically". This collaborative writing project weighed $25 \%$.

In regard to regulation activities, individuals and students in groups were required to record and report their weekly practices in regulation pages. For personal regulations, the person had to identify the goal in the writing process. After that, the person had to write the reflections in a journal 
to monitor and evaluate the progress of writing. For the goal in groups, they discussed weekly goals and directions in the writing process. They also assigned different workload to different group members so that all the members of the group are able to play their roles effectively. For the monitoring process, each group examined its writing process and compared it to other groups in terms of goals and accomplishments. For the evaluation process, it was a revision process to determine the evaluation standards when grading the write-ups. The regulation activities weighed $5 \%$.

\section{Instruments}

In this study, three instruments namely writing motivations, writing satisfactions and log files were used to collect data. The subscales of writing motivations were inclusive of (i) ability to write (Daly \& Miller 1975), (ii) anxiety about writing (Daly \& Miller 1975) and (iii) strategies used to write (Zimmerman \& Bandura 1994). The formers were evaluated with a Likert scale that ranged from 1 (strongly disagree) to 7 (strongly agree). The latter was adapted from Writing Self-Regulatory Efficacy scale that ranged from 0 (cannot do all) to 10 (highly certain can do). These three subscales showed Cronbach's alpha .75, .90, .97 respectively, exhibiting high reliability. Table 2 showed the details of each subscales.

Besides, log files recorded in wikis for 5 weeks were served as a platform to examine students' actual collaborative participations. Actual collaborative participations referred to adding in ideas, revising ideas and editing work. Students had contributed 500 times of posts on wikis. The contributions of students' postings to collaborative writing in these 6 weeks was $15.70(S D=8.95)$.

The scales for the levels of satisfactions with regulation activities were adapted from learning team survey (LTS) (Faidley, Evensen, Salisbury-Glennon, Glenn \& Hmelo 2000) and open-ended questions were developed to collect data. LTS was a Likert scale ranged from 1 (never) to 7 (always) employed to measure the dynamic aspects of collaboration that consisted of soft skills, conflict in team, responsibility, group performance, purpose, common approach and group satisfaction. Cronbach's alpha was from .71 to .94 (Table 2). There were 2 open-ended interview questions designed to determine whether regulation activities helped participants (individuals and groups) in the collaborative writing process. The two interview questions were (i) How was the self regulation useful in the writing process? And (ii) How was the group regulation useful in the writing process?

\section{Research Procedures}

All the participants were required to fill out a consent form before they were allowed to take part in this research. A briefing was held in a computer lab on week 4 . The purpose of the briefing was to explain the ways of managing wikis and the functions of regulation activities in wikis. Participants had to fill out the instrument of motivation available online before and after the participations took part in the process of collaborative writing and regulation activities in wikis, the virtual platform. The writing satisfaction, on the other hand, was administered to the students prior to the completion of research. Participants had to submit their log files after the completion of the project. 
INTERNATIONAL JOURNAL OF ACADEMIC RESEARCH IN BUSINESS AND SOCIAL SCIENCES

Vol. 8, No. 12, Dec, 2018, E-ISSN: 2222-6990 @ 2018 HRMARS

Table 2. Details for Motivation in Writing \& Learning Team Survey

\begin{tabular}{|c|c|c|c|c|}
\hline & $\begin{array}{l}\text { Number } \\
\text { of items }\end{array}$ & Likert scale & $\begin{array}{l}\text { Cronbach's } \\
\text { alpha }\end{array}$ & Reponses \\
\hline \multicolumn{5}{|l|}{ Motivation in writing } \\
\hline Ability to write & 4 & 7 & .72 & I am a proficient writer \\
\hline Anxiety about writing & 6 & 7 & .91 & $\begin{array}{l}\text { I am frightened of writing } \\
\text { freely when my work is } \\
\text { assessed. }\end{array}$ \\
\hline Strategies used to write & 24 & 11 & .97 & $\begin{array}{l}\text { I could use transitional } \\
\text { sentences to join the ideas } \\
\text { effectively }\end{array}$ \\
\hline \multicolumn{5}{|l|}{ Learning team survey } \\
\hline Soft skills & 9 & 7 & .96 & $\begin{array}{l}\text { My group members were } \\
\text { very decisive }\end{array}$ \\
\hline Responsibility & 4 & 7 & .75 & $\begin{array}{l}\text { The team members held } \\
\text { one another accountable }\end{array}$ \\
\hline Conflict in the team & 5 & 7 & .94 & $\begin{array}{l}\text { There were lots of } \\
\text { disputes in my group }\end{array}$ \\
\hline Group performance & 6 & 7 & .75 & My group did well \\
\hline Purpose & 6 & 7 & .87 & $\begin{array}{l}\text { Team members were clear } \\
\text { of their roles }\end{array}$ \\
\hline Common approach & 5 & 7 & .85 & $\begin{array}{l}\text { Members adhere to due } \\
\text { dates }\end{array}$ \\
\hline Group satisfaction & 5 & 7 & .86 & $\begin{array}{l}\text { I am happy working with } \\
\text { my group members }\end{array}$ \\
\hline
\end{tabular}

\section{Results}

\section{Impact of regulation activities on students' confidence in and writing anxiety}

A dependent $t$-test was employed to make comparisons between the means of students' ability to write, writing anxiety and strategies used in collaborative writing process. $T$-test was used to calculate the differences pre- and post- regulation activities on the wiki (see Table 3). From the result on the ability to write, it did not significantly show its improvements after the completion of regulation activities: $\mathrm{t}(30)=-1.29, \mathrm{p}=.215$. The writing anxiety was clearly reduced after the completion of regulation activities: $\mathrm{t}(30)=2.39, \mathrm{p}=.027$, Cohen's $\mathrm{d}=0.34$. This result indicated that a small to medium size effects on writing anxiety. Effect size refers to the impact levels for treatment in writing. 
INTERNATIONAL JOURNAL OF ACADEMIC RESEARCH IN BUSINESS AND SOCIAL SCIENCES

Vol. 8, No. 12, Dec, 2018, E-ISSN: 2222-6990 C 2018 HRMARS

Careful interpretations of the effect of treatment were needed when the effect size was from small to medium. The effect size from small Students' writing strategies had significantly changed after the regulation activities: $t(30)=-2.55, p=.016$, Cohen's $d=0.32$. It has shown a small to medium size effects of regulation activities on using writing strategies.

Table 3. Pre- and Post- Mean and Standard Deviation for ability to write, writing anxiety and writing strategies.

\begin{tabular}{|l|c|c|c|c|c|}
\hline \multirow{2}{*}{ Items } & \multicolumn{2}{c|}{ Pre } & \multicolumn{2}{c|}{ Post } & \multirow{2}{*}{ Sig. } \\
\cline { 2 - 5 } & $\mathrm{M}$ & SD & $\mathrm{M}$ & SD & \\
\hline Ability to write & 4.63 & 1.35 & 4.88 & 0.98 & $>.05$ \\
\hline Writing Anxiety & 3.22 & 1.64 & 2.72 & 1.48 & $<.05$ \\
\hline Writing Strategies & 7.97 & 1.65 & 8.48 & 1.57 & $<.05$ \\
\hline
\end{tabular}

Relationships between students' ability to write, writing anxiety, writing strategies and the real writing practices

The nine groups recorded 440 log files. The content analysis was conducted to assess the log files posted on wikis. Meishar-Tal and Gorsky's (2010) coding schemes for wikis were employed to perform the content analysis. The $20 \%$ of the log files written the first student was used to develop a coding scheme. The researcher had coded 530 themes from 440 log files because each log file might have more than one themes. $89 \%$ of the two coders were extracted from the whole set of log files. Group discussion was conducted to resolve the discrepancies.

Table 4 was the results of content analysis and it showed the specified figures of frequency on each theme. The results of content analysis showed that a lot of students were active users in the collaborative writing process especially sharing their ideas on their wikis. About the theme in writing, adding new insights to the wiki was a common practice in the writing process, followed by correcting grammar, improving content and reviewing and editing formats. 
INTERNATIONAL JOURNAL OF ACADEMIC RESEARCH IN BUSINESS AND SOCIAL SCIENCES

Vol. 8, No. 12, Dec, 2018, E-ISSN: 2222-6990 @ 2018 HRMARS

Table 4. Themes coded for students' writing practices

\begin{tabular}{|c|c|c|c|c|c|}
\hline Theme & Frequency & $\%$ & $M$ & SD & Explanation \\
\hline Total contributions & 530 & 100.00 & 19.69 & 10.54 & $\begin{array}{l}\text { It was calculated based on adding in } \\
\text { new ideas, revising content, revising } \\
\text { grammar, format and reviewing }\end{array}$ \\
\hline Adding new insights & 247 & 46.60 & 9.18 & 4.97 & $\begin{array}{l}\text { Sharing students own thought into the } \\
\text { project or applying other useful } \\
\text { resources into the assignment }\end{array}$ \\
\hline Improving content & 69 & 13.03 & 2.50 & 2.55 & Changing ideas in their writing \\
\hline Revising grammar & 125 & 23.58 & 4.54 & 3.22 & $\begin{array}{l}\text { Changing tenses, structures of } \\
\text { sentences, spelling, punctuations }\end{array}$ \\
\hline Editing formats & 50 & 9.44 & 1.86 & 1.79 & $\begin{array}{l}\text { Changing headings, subheadings } \\
\text { references, citations }\end{array}$ \\
\hline Reviewing & 39 & 7.35 & 1.39 & 1.84 & $\begin{array}{l}\text { Students made no changes but they } \\
\text { logged onto group wikis. By } \\
\text { assumption, students reviewed group } \\
\text { writing }\end{array}$ \\
\hline
\end{tabular}

* note: The frequencies on themes were calculated using means (M) and standard deviation (SD).

Table 5 showed the correlation analysis for the variables. The correlation showed the relationships between students' ability to write, writing anxiety, writing strategies and real collaborative writing process. The ability to write among students was positively referred to the total postings on wikis, adding new insights and revising grammar but the writing anxiety showed negative associations with the themes. However, the students' writing strategies was positively associated with the total postings on wikis and editing formats.

Table 5. Relationships between confidence, writing themes and anxiety on wikis.

\begin{tabular}{|c|c|c|c|c|c|c|c|c|c|}
\hline Items & 1 & 2 & 3 & 4 & 5 & 6 & 7 & 8 & 9 \\
\hline a. Writing strategies & 1 & & & & & & & & \\
\hline b. Ability to write & $.62^{* *}$ & 1 & & & & & & & \\
\hline c. Anxiety about writing & -.15 & -.37 & 1 & & & & & & \\
\hline d. Total file logs on wikis & $.46 *$ & $.56^{* *}$ & $-.49 *$ & 1 & & & & & \\
\hline e. Adding ideas & .35 & $.52 * *$ & $-.46^{*}$ & $.82 * *$ & 1 & & & & \\
\hline f. Revising contents & .27 & .18 & -.32 & $.72 * *$ & $.43^{*}$ & 1 & & & \\
\hline h. Editing grammar & .36 & $.54 * *$ & $-.37^{*}$ & $.87^{* *}$ & $.52 * *$ & $.46^{*}$ & 1 & & \\
\hline i. Editing formats & $.46^{*}$ & .37 & -.27 & $.64 * *$ & .38 & .33 & .36 & 1 & \\
\hline j. Reviewing & .12 & .34 & -.25 & $.46^{*}$ & -.05 & .32 & $.58 * *$ & $.45^{*}$ & 1 \\
\hline
\end{tabular}

$* p<.05^{* *} p<.01$ 
INTERNATIONAL JOURNAL OF ACADEMIC RESEARCH IN BUSINESS AND SOCIAL SCIENCES

Vol. 8, No. 12, Dec, 2018, E-ISSN: 2222-6990 @ 2018 HRMARS

\section{Students' satisfaction with collaborative teamwork and regulation activities}

In this analysis, descriptive data analyses were employed to evaluate students' satisfactory items when working with groups in which regulation activities were conducted. Table 6 revealed that students showed total satisfactions with the collaborative writing process on wikis.

Table 6. Learning Team Survey (LTS) to show students' satisfaction

\begin{tabular}{|l|c|c|}
\hline \multicolumn{1}{|c|}{ Items } & M & SD \\
\hline a. Soft skills & 6.54 & .82 \\
b. Responsibility & 6.49 & .89 \\
c. Team conflict & 1.83 & 1.79 \\
d. Team performance & 6.48 & .76 \\
e. Purpose & 6.34 & .76 \\
f. Common approach & 6.48 & .74 \\
g. Group satisfaction & 6.45 & 1.07 \\
\hline
\end{tabular}

* note: Scales for LTS ranged from 1 (never) to 7 (always). For the conflicts in the team, mean inclination was close to 1 . It indicated that members of the team had no conflict but 7 showed that high conflict among the team members.

Two interview questions were designed to examine undergraduates' level of satisfaction with the regulation activities embedded in collaborative writing on wikis. Fifteen students commented that personal regulation had provided ample chances for them to come up with their goals in writing, devise ways to write effectively, monitor the progress and evaluate their ideas. This process enabled them to focus comprehensively on their weekly collaborative writing. One commented:

I was excited to be given the opportunities to set my goals in writing. I did accomplish my weekly goals and they really helped me to get my tasks done on time. I believed that if I did not set my goals, I would definitely procrastinate my progress.

Besides, ten students agreed that group regulation was useful as it had given the opportunities to share their ideas in the writing process. Students were not only able to discuss their goals in writing but also monitor and evaluate their writing process. Each student had their own role so they could write their outlines, check their peers' progress and support one another effectively. One supported:

The journal entries helped us to reflect my writing process effectively. It was a way to monitor and help my group members to complete their task progressively. It was helpful as I am able to show my strengths and the tasks to be completed before the due date so that I could edit the work together with my group members properly.

However, three students viewed the regulation activities were unhelpful because they were independent and deemed the regulation activities as a time-consuming process as they had to wait 
for other group members for their inputs before they were able to complete the tasks. Two students thought that the process for goal setting, monitoring and evaluation were sometimes a repetition because the weekly teaching plans in the class had helped students to complete their writing tasks progressively.

\section{Discussions}

This study have provided important references for instructors and educational developers in a higher institution to commence the use of wikis in collaborative writing processes. Cole (2009) criticized that collaboration on wikis seemed not to encourage students to take part actively in their learning. In his study (2009), he discovered that the students seldom took part in the collaborative writing tasks on wikis although they were savvy in technology and interested in team work. However, undergraduates who took part actively in the collaborative writing process indicated high satisfaction. It had clearly shown that regulation activities incorporated in collaboration yielded positive effects.

Besides, De Weaver et al. (2015) and Jeong (2017) had commented that intervention for the students' participations in collaborative writing process on the virtual platform was scarcely researched. The present study had demonstrated the methods to promote collaborative efforts among university students. This study also showed that the increment of confidence for students using writing strategies and the reduction of students' writing anxiety after they participated in virtual regulation activities. In regard to the relationships between confidence, anxiety and real writing practices as shown in Table 5, students' confidence to employ the writing strategies as well as the ability to write had to be improved and the writing anxiety had also to be reduced so that they were able to participate actively in collaborative writing process on wikis.

In addition, students were given ample opportunities to prompt regulation externally because regulation was an effective tool in their learning process. Azevedo, Moos, Greene, Winters and Cromley (2008) had discovered that students who experienced external prompts had significantly acquired additional knowledge and developed a better cognitive model on post-tests. They further claimed that students with external prompting had engaged effectively in the regulation process. Dignath and Buttner (2008) agreed that external prompts which embedded with course materials are more effective than other methods in improving regulation.

Educational developers are able to employ the intervention of this study and its results to guide the instructors when implementing collaboration projects with students on wikis. They have to design the course where the students are given ample opportunities to meet their peers during class hours. Many of them valued the face-to-face classroom meetings and also appreciated the facilitations of smooth group regulation. This is consistent with the outcome of O'Bannon, Luke and Britt (2013) that students were expected to meet face-to-face with their peers for better discussions and communication when collaborating on wikis.

Finally, educational developers can guide the instructor that students are required to carry out either individual or group regulations on wikis for their collaborative writing process. Although 
the theory for self and group regulations are different, students' comments had demonstrated that both was repetitive. The students preferred group regulation activities because they had allowed them to gather together the strengths among individuals to progress. Hence, educational developers had to render guidance to instructors to use the regulation activities effectively because the instructors may have preferences when employing individual or group or both regulations. The designs of the types of regulations should be based on the course contexts so students are able to achieve their learning goals through the different types of regulations applied.

\section{Limitation}

Two limitations were identified in this study. The present study had only experimental groups but had no control groups. Thus, it is short of face value validity and limits the interpretations of the effects on collaborative writing process. As a result, the designed regulation activities cannot be argued as the sole improvement for the confidence in using writing strategies or reduction of writing anxiety. In addition, the size of participants was small $(n=30)$ and thus generalization is narrow. Researchers may expand this small-scale study by engaging students from different disciplines in the future. This may enhance generalizability.

\section{References}

Azevedo, R., Moos, D. C., Greene, J. A., Winters, F. I., \& Cromley, J. G. (2008). Why is externally facilitated regulated learning more effective than self-regulated learning with hypermedia? Educational Technology Research \& Development, 56, 45-72.

Bruning, R., Dempsey, M., Kauffman, D. F., McKim, C., \& Zumbrunn, S. (2013). Examining dimensions of self-efficacy for writing. Journal of Educational Psychology, 105, 25-38. https://doi.org/10.1037/a0029692

Chappelle, C. 1997. CALL in the year 2000: Still in search of research paradigms? Language Learning \& Technology, 1: 19-43.

Charney, D., Newman, J. H., \& Palmquist, M. (1995). 'I'm just no good at writing': Epistemological style and attitudes toward writing. Written Communication, 12, 298-329. https://doi.org/10.1177/0741088395012003004

Cole, M. (2009). Using wiki technology to support student engagement: Lessons from the trenches. Computers \& Education, 52, 141-146.

Daly, J. A., \& Miller, M. D. (1975). The empirical development of an instrument to measure writing apprehension. Research in the Teaching of English, 9, 242-249.

De Weaver, B., Hämäläinen, R., Voet, M., \& Gielen, M. (2015). A wiki task for first-year university students: The effect of scripting students' collaboration. Internet and Higher Education, 25, 37-44.10. https://doi.org/1016/j.iheduc.2014.12.002 
INTERNATIONAL JOURNAL OF ACADEMIC RESEARCH IN BUSINESS AND SOCIAL SCIENCES Vol. 8, No. 12, Dec, 2018, E-ISSN: 2222-6990 C 2018 HRMARS

Dignath, C., \& Büttner, G. (2008). Components of fostering self-regulated learning among students. A meta-analysis on intervention studies at primary and secondary school level. Metacognition and Learning, 3, 231-264. https://doi.org/10.1007/s11409-008-9029-x

Faidley, J., Evensen, D. H., Salisbury-Glennon, J., Glenn, J., \& Hmelo, C. E. (2000). How are we doing? Methods of assessing group processing in a problem-based learning context. In D. H.Evensen \& C.

E. Hmelo (Eds.), Problem-based learning: A research perspective on learning interactions (pp. 109-135). Hillsdale, NJ: Erlbaum.

Felix, U. 2005. Analysing recent CALL effectiveness research - Toward a common agenda. Computer Assisted Language Learning, 18(1-2): 1-32.

Gallavan, N. P., Bowles, F. A., \& Young, C. T. (2007). Learning to write and writing to learn: Insights from teacher candidates. Action in Teacher Education, 29, 61-69.

https://doi.org/10.1080/01626620.2007.10463449

Haixia Liu, Chin-Hsi Lin, Dongbo Zhang. (2017) Pedagogical beliefs and attitudes toward information and communication technology: a survey of teachers of English as a foreign language in China.

Computer Assisted Language Learning, 30:8, pages 745-765.

Hammann, L. (2005). Self-regulation in academic writing tasks. International Journal of Teaching and Learning in Higher Education, 17, 15-26.

Hubbard, P. 2005. A review of subject characteristics in CALL research. Computer Assisted Language Learning, 18: 351-368.

Järvelä, S., Kirschner, P.A., Panadero, E., Malmberg, J., Phielix, C., Jaspers, J.,\& Järvenoja, H.(2015). Enhancing socially shared regulation in collaborative learning groups: Designing for CSCL regulation tools. Educational Technology Research and Development, 63, 125-142. https://doi.org/10.1007/s11423-014-9358-1

Karasavvidis, I. (2010). Wiki uses in higher education: Exploring barriers to successful implementation. Interactive Learning

Environments, 18, 219-231. https://doi.org/10.1080/10494820.2010.500514

Kyeong-Ouk Jeong. (2017) Preparing EFL student teachers with new technologies in the Korean context. Computer Assisted Language Learning 30:6, pages 488-509.

Martinez, C. T., Kock, N., \& Cass, J. (2011). Pain and pleasure in short essay writing: Factors predicting 
INTERNATIONAL JOURNAL OF ACADEMIC RESEARCH IN BUSINESS AND SOCIAL SCIENCES Vol. 8, No. 12, Dec, 2018, E-ISSN: 2222-6990 C 2018 HRMARS

university students' writing anxiety and writing self-efficacy. Journal of Adolescent \& Adult Literacy, 54, 351-360.

Megele, C. (2015). eABLE: Embedding social media in academic curriculum as a learning and assessment strategy to enhance students learning and e-professionalism. Innovations in Education and Teaching International, 52, 414-425. https://doi.org/ 10.1080/14703297.2014.890951

Meishar-Tal, H., \& Gorsky, P. (2010). Wikis: What students do and do not do when writing collaboratively. Open Learning, 25, 25-35. https://doi.org/10.1080/02680510903482074

O’Bannon, B. W., Lubke, J., \& Britt, V. G. (2013). You still need that face-to-face communication: Drawing implications from preservice teachers' perceptions of wikis as a collaborative tool. Technology, Pedagogy, and Education, 22, 135-152. https://doi.org/10.1080/1475939X.2012.755470

Pekrun, R., Goetz, T., Daniels, L. M., Stupnisky, R. H., \& Perry, R. P. (2010). Boredom in achievement settings: Exploring control-value antecedents and performance outcomes of a neglected emotion. Journal of Educational Psychology, 102, 531-549. https://doi.org/10.1037/a0019243

Soh, Or-Kan, Hong-Fa, Ho. (2014). Students' Perceptions Towards the Use of Dialogic Feedback in Mobile Applications for Students' Writing: A Case Study, Journal of e-Learning and Knowledge Society, v.10, n.3, 37-49.

Stockwell, G. 2007a. A review of technology choice for teaching language skills and areas in the CALL literature. ReCALL, 19: 105-120.

Su, F., \& Beaumont, C. (2010). Evaluating the use of a wiki for collaborative learning. Innovations in Education and Teaching International, 47, 417-431. https://doi.org/10.1080/14703297.2010.518428

Volet, S., Vauras, M., \& Salonen, P. (2009). Self- and social regulation in learning contexts: An integrative perspective. Educational Psychologist, 44, 215-226.

https://doi.org/10.1080/00461520903213584

Wheeler, S., \&Wheeler, D. (2009). Using wikis to promote quality learning in teacher training. Learning, Media and Technology, 34, 1-10. https://doi.org/10.1080/17439880902759851

Winne, P. H., \& Hadwin, A. F. (1998). Studying as self-regulated learning. In D. J. Hacker, J.Dunlosky, \& A. Graesser (Eds.), Metacognition in educational theory and practice (pp. 277304). Hillsdale, NJ: Erlbaum. 
INTERNATIONAL JOURNAL OF ACADEMIC RESEARCH IN BUSINESS AND SOCIAL SCIENCES Vol. 8, No. 12, Dec, 2018, E-ISSN: 2222-6990 C 2018 HRMARS

Witney, D., \& Smallbone, T. (2011). Wiki work: Can using wikis enhance student collaboration for group assignment tasks? Innovations in Education and Teaching International, 48, 101-110. https://doi.org/10.1080/14703297.2010.543765

Zimmerman, B. J., \& Bandura, A. (1994). Impact of self-regulatory influences on writing course attainment. American Educational Research Journal, 31, 845-862. https://doi.org/10.3102/00028312031004845

Zimmerman, B. J., \& Schunk, D. (2011). Handbook of self-regulation of learning and performance. New York, NY: Routledge. 